\title{
Perceptions of Good and Bad Leaders by Philippine Teachers
}

\author{
Raymond A. Zepp ${ }^{1}$ \\ ${ }^{1}$ Dewey International University, Battambang, Cambodia \\ Correspondence: Raymond A. Zepp, Dewey International University, Battambang, Cambodia. \\ Received: January 10, 2018 \\ Accepted: January 30, 2018 \\ Online Published: February 21, 2018 \\ doi:10.5430/jms.v9n1p66 \\ URL: https://doi.org/10.5430/jms.v9n1p66
}

\begin{abstract}
The research attempted to answer the question: "What do Philippine teachers perceive as important traits and behaviors of good and bad leaders?" Related to this were three sub questions:

1. How do Philippine teachers compare with those in other countries in their perceptions on leadership?

2. Do male and female Philippine teachers share similar perceptions on leadership?

3. Do old and young Philippine teachers share similar perceptions on leadership?

A questionnaire asked 90 Filipino teachers to rank their top three choices from among 8 traits of good leaders, then among 8 behaviors of good leaders, then 8 traits of bad leaders, and finally 8 behaviors of bad leaders. Comparisons were then drawn between the Philippine results and those in other countries, as well as between males and females within the Philippine sample, and younger and older Philippine teachers.

Philippine teachers clearly valued honesty as the most important trait, and showing respect as the most important behavior of a good leader. This result is slightly different from that of some other countries, where, for example, intelligence or dependability was deemed the most important trait.

Further, the study revealed several significant differences on several items between men and women, as well as between old teachers and young teachers.
\end{abstract}

Keywords: leadership, Philippines, trait, behaviour, cross-cultural, teachers

\section{Introduction}

\subsection{Background of the Topic}

All over the world, experts and management gurus are running workshops on how to be good leaders. These workshops usually have one aspect in common: they assume that there is one and only one way to be a good leader. An American leadership expert, for example, goes to Asia and projects American ideals of good leadership, as though that is the only type of leadership that works.

Leadership theory has evolved greatly over the past century. Early theories focused on universal traits of good leaders (Stogdill, 1948), and those theories then branched into ones about behaviors of good leaders (i.e. what a good leader does rather than what a good leader is). (Likert, 1961)

It was soon realized that a host of 'contingencies' determine optimum styles of leadership. A 'country-club' style focuses on the well-being of the people being led. This is quite the contrary of a military leader, who is interested only in results, regardless of how contented the soldiers are. These contingency theories led naturally to a realization that different cultures may perceive good and leaders differently. The cultural classifications of Hofstede (1984) were pioneering in this sense, and his categorization scheme holds up even today as a way of looking at how different cultures may value various traits and behaviors of leaders. Hofstede has, however, been criticized over the years, mostly for his focus on entire countries, which may have vastly different subcultures within their boundaries. Further, Hofstede studied his values before 1984, so his rankings may have changed over the past 34 years. (Jones, 2007)

Perceptions of leadership traits and behaviors have already been studied in many cultures, such as the United States, China, Japan, and several other Asian countries. Relatively little research has been done in the Philippines. This paper aims to add data on Philippine perceptions of leadership to add to the growing collection of data on countries and cultures around the world. 
It is understood from the above discussion of contingency theories that perceptions may also vary from one profession or subculture to another. It would therefore be futile to investigate the perceptions of all possible subcultures and professions in the Philippines. Therefore, the present study is limited to teachers on the northern Philippine island of Luzon. Further, the number of elementary to secondary teachers is kept to a 2:1 ratio similar to that of other studies in other countries.

\subsection{Problem Statement}

Leadership theories have become more and more 'contingency' oriented over the past half-century. Different situations call for different leadership styles. This has been shown to be true for culturally different situations, where a leadership style preferred in one culture is not preferred in another.

This paper will explore leadership styles in the Philippines. The main question addressed by this research was: What traits and behaviors of good and leaders are considered most important by Philippine teachers? Secondary questions were the following:

1. How do Philippine teachers compare with those in other countries with regard to their perceptions on leadership?

2. Do male and female Philippine teachers share similar perceptions on leadership?

3. Do older and younger Philippine teachers share similar perceptions on leadership?

\subsection{Situation in the Philippines}

According to the Hofstede classification scheme (op. cit.), Philippine culture is marked by high 'power distance', that is, respect for authority and strict hierarchies of power, and by low 'individualism', that is, a collective way of working in groups or families. The United States is just the opposite, with an egalitarian low power distance but a high coefficient for individualism. One might therefore expect differences in the perceptions of good and bad leaders between Philippine and American teachers. For example, Philippine leaders may be more authoritarian than American leaders (of course, not forgetting Ferdinand Marcos), but not as egalitarian as American leaders.

\subsection{Overview of Methodology}

A questionnaire has already been developed by foreign researchers, and used in several cultures and professions. The same questionnaire was given to 60 primary and 30 secondary teachers in the Philippines. The questionnaire asks respondents to rank eight traits of good leaders, eight behaviours of good leaders, eight traits of bad leaders, and eight behaviours of bad leaders, in the order of their perceived importance. The selection of these traits for inclusion in the questionnaire was based on the original studies of Stogdill (op. cit., 1948), and the behaviors were drawn from those of Likert (op. cit. 1961).

These rankings can be tabulated and mean rankings calculated for each trait and behavior. These mean rankings can then be compared statistically with one another, and with mean rankings in other cultures.

In each of the four sections, mean scores for each item were calculated, so that the eight items could be compared from most important to least important, as perceived by the teachers. In addition, scores for each item were compared between male teachers and female teachers, as well as between older teachers (> 36 years) and younger teachers $(<$ 37 years).

Since similar data exist for other countries, using the same questionnaire, it was possible to compare the Philippine results with those of seven other countries to see whether Philippine teachers had similar perceptions of leadership to teachers in other countries. Any differences in rankings between Philippine teachers and teachers in other countries can be discussed in the light of Hofstede's categories and other international research findings.

Finally, attempts will be made to apply the findings to the educational system in the Philippines, so that the training and selection of educational leaders will have certain criteria for determining who will be perceived as a good or bad leader.

\subsection{Delimitations}

1. The study leaves open the question of whether these types are actually better leaders. Actual leadership that produces the desired results may be different from perceived ideals. This research deals only with perceptions of good and bad leaders, not actual results.

2. The sample is limited to teachers, not school administrators, who may have a different perception of leadership. The sample was be drawn from convenient areas of the Philippines, and so was not completely 
random. The assumption is made that various areas of the country are roughly equivalent, an assumption implicit in Hofstede's work.

\section{Review of Relevant Literature}

What makes a good leader? The answer is: "it depends." It depends on a host of factors, many of which are cultural. The literature reviewed in this chapter shows that the history of leadership theory has moved from a listing of universal traits and behaviors to a more splintered description which looks at the differing traits and behaviors important for leadership in a variety of countries, professions, and other cultural groups.

This paper investigates the perceptions of leadership by Philippine teachers. Such an investigation is based on the hypothesis that there may be cultural differences between the perceptions of Philippine teachers and teachers in other countries. It is therefore useful to examine the literature in support of this thesis concerning cultural differences in leadership.

In the early days of leadership theory, it was generally assumed that a set of traits and behaviors could be identified which typified all good leaders. Thomas Carlisle (1840) addressed the question 175 years ago. His 'Great Man' theories assumed that leaders were born, not made, and that they could be identified by certain inborn traits.

The pioneering Ohio State studies by Stogdill (1948) set out a list of traits common to good leaders. However, these studies were done in the Midwestern United States culture, with no thought that perhaps different results would be obtained in a different culture. Around the same time, the Michigan studies, led by Likert (1961) focused on leaders' behaviors. That is, they examined what a good leader does, rather than what a good leader is. Again, these behaviors were studied in the United States, and in the 1950s, the notion of cultural differences in leadership preferences was only in its infancy.

By the 1980s, researchers realized that good leadership was contingent on several factors. Notably, Blake and Mouton (2004) cited different situations or subcultures that required different leadership styles. For example, a 'country-club' style of leadership should aim at 'people-oriented' outcomes. On the other hand, a military leader's goal is to defeat the enemy, even if it means the soldiers being led are not being pampered. This requires a 'results-oriented' style of leadership. Blake and Mouton developed a 'leadership grid' that placed a situation as a point defined by two axes: the personal axis and the product axis.

The Blake and Mouton approach hinted at the fact that different cultures might have different notions of good and bad leadership. A country may more or less closely resemble the 'country-club' culture or the 'authority-compliance' culture.

House, et al. (2004) tried to answer the question of cultural relativity in a large "GLOBE" study of 17,000 managers in 62 cultures. They isolated 22 traits that everyone could agree upon as characteristics of outstanding leadership. The weakness of this approach, however, was that the relative importance of those traits was not addressed. We might all agree that a leader should be intelligent, for example, but some cultures may value intelligence as more important or less important than other traits.

The real breakthrough came with the work of Hofstede (1983), who analyzed characteristics of various cultures. He posited four major cultural variables: power distance, uncertainty avoidance, masculinity, and individualism vs. collectivism. In later work, he added a fifth dimension, that of long-term vs. short-term planning. These categories provided a framework for studying management and leadership. For example, a culture that displayed strong power distance (i.e. respect for authority), might prefer more authoritarian leaders.

In fact, Hofstede constructed a table of many countries, including the Philippines and the United States. The figures shown below compare the ratings of the Philippines and the United States across the five dimensions: PDI (Power Distance Index), IDV (Individualism vs. Collectivism), MAS (Masculinity), (UAI)Uncertainty Avoidance Index), and LTO (Long-term Orientation). The following are Hofstede's ratings on the five dimensions for the Philippines and the United States:

$\begin{array}{llllll} & \text { PDI } & \text { IDV } & \text { MAS } & \text { UAI } & \text { LTO } \\ \text { Philippines } & 94 & 32 & 64 & 44 & 19 \\ \text { United States } & 40 & 91 & 62 & 46 & 29\end{array}$

The data show that the Philippines and the United States differ greatly in Power Distance and Individualism. In practice, therefore, we might expect Filipinos to prefer a more authoritarian leadership style, while Americans might prefer a more individualistic style. 
Finally, recent research has verified what Blake and Mouton were saying, namely, that even within a culture or country, different situations (such as different jobs) require different leadership styles. For example, in Cambodia, Zepp (2011) studied perceptions of good and bad leaders in various professions, and found different perceptions among the professions. Even within the educational world, teachers and students may display different perceptions of good and leaders (Zepp, 2009b).

\subsection{Educational Leadership in the Philippines}

First and foremost, it must be emphasized that the Philippines is far from a uniform culture. There are approximately 120 languages (Baldauf, 2006). Philippine culture has been influenced by the Spanish, the Americans, and the Indonesian Moslems in the South. Since these various occupiers have had greater or lesser influence in certain areas, the entire island group has large regions of varying cultural influence, including in particular differences in religion among Catholic, Protestant, Muslim, and local animist cultures.

This is despite efforts to develop a sense of national identity by focusing on common elements found across the Philippine cultures. The creation of a national language, Filipino, based largely on the Tagalog language, was aimed at unifying the diverse language groups.

Zialcita (2005), on the contrary, points out that

Today, however, the notion of a "national culture" is under attack, for what is called a "nation" is not monolithic. It brings together peoples who differ from each other in religion, ethnicity, social class, and gender.

Little empirical research on Educational leadership has been done in the Philippines. (Luna, 2012) In particular, Luna points out that most of the research into Philippine leadership is done in fields outside education. "Most leadership programs in the Philippines launched by the government and/or sponsored by other countries focus more on training for government positions and fail to represent other sectors especially education."

Among the few studies available, a dissertation on leadership traits in higher education by Bumatay (2004) among university deans concluded:

They placed high premium on good moral character, moral uprightness or trustworthiness and personal integrity as important strength, trait and attribute of a leader. Indicator of leadership success was through work relationships. Filipino leaders are distinct as role models and manage through a people oriented and values-driven style.

Regarding leaders' behaviors, San Antonio and Gamage (2005), identified factors in the behaviors affecting stakeholder's commitment levels in a school in the Philippines:

- Supportive (open to suggestions, recognizes others, approachable, resourceful, transparent, fair, strict, respect others, trusts others, sincere

- pro-active (active, prompt, enthusiastic, innovative, dedicated)

- gives priority to school or student welfare

- behaving in cooperative and admirable ways (well-behaved, high moral values, helpful, committed, encourages others, present good ideas, open to ideas of others, knows how to control emotions).

Negative behaviors included:

- lacking in decisiveness

- over-manifestation of their traditional authority (frank, monopolizing discussions, gives no sufficient freedom to express sentiments, being authoritarian, arrogant, sarcastic, ill-tempered)

A study of educational leadership in the far northeast of the Philippines (Sindhvad, 2009) found that 59\% of the principals observed displayed a democratic style of leadership, while $16(32.7 \%)$ and four $(8.2 \%)$ showed the free-reign and autocratic leadership style, respectively. However, "Sex, age, civil status, length of service as principal, highest educational attainment, and position had no significant relationship with leadership styles of elementary school principals."

Thus, a few studies have addressed the questions of behaviors and traits of good and bad leaders. However, there has been little attempt, if any, to rank or prioritize the traits or behaviors as to their relative perceived importance. 


\subsection{Literature Summary}

In summary, it appears that people all over the world can agree on several traits and behaviors of good and bad leaders, but their relative ranking of these traits varies greatly according to many factors.

As for the Philippines, one general trend among the studies stands out, namely, the fact that the Philippines are undergoing rapid globalization, and that this globalization and the trend to create a national Philippine identity, produces considerable tension with the opposite drive to preserve local and tribal identities. Leaders are having difficulty coping with this change. In addition, these changes are leading to changes and challenges in leadership styles. Educational leaders must attempt to bring the various regions of the country into the global economy and culture, while fostering a sense among students and teachers of their local heritage.

\section{Methodology}

\subsection{Purpose and Research Perspective}

The research is designed to answer the questions raised in the problem statement above.

The research takes a quantitative perspective. It attempts to measure the relative strengths of teachers' perceptions of the traits and behaviors of good and bad leaders as laid out in the main question above. The word 'relative' is key here, because the study attempts to show that some traits and behaviors, all of which may be desirable, are more desirable than others in the view of teachers in northern Philippines.

The research also assesses whether these relative importances are related to the age and sex of respondents. These comparisons are the outgrowth of sub questions 2 and 3 listed above.

The data compiled from the questionnaires are then compared to similar data recorded in seven other countries. These countries represent a wide range of cultures in Asia, the Middle East, and America. This partially responds to sub question one above.

The research was carried out by using a survey questionnaire. The questionnaire asks respondents to rank their three most important traits of good leaders, as chosen from a list of eight traits. Similarly, section 2 of the questionnaire asks the teachers to rank their three most important behaviors of good leaders. Section 3 asks them to rank their three most important traits of bad leaders, and section 4 asks them to rank their three most important behaviors of bad leaders.

The questionnaire was designed to measure perceptions of international groups. It has been used in previous studies in several cultures around the world, such as Cambodia, Qatar, United States, Taiwan, Pakistan, Hong Kong, and Uganda.

The questions are shown in Appendix A at the end of the paper.

\subsection{Sample}

Respondents were chosen from schools in a narrow geographical area in Isabela Province, Northern Luzon, Philippines. This narrow scope was chosen to avoid regional differences in responses that might occur. Teachers were chosen from eight schools in the vicinity of Alicia/San Guillermo. Within each school, all teachers took the questionnaire, so there could be no bias due to self-selection of teachers who chose to fill out the questionnaire.

Following the practice of the three studies cited above, a sample size of 100 teachers was targeted, with approximately $2 / 3$ of the teachers coming from primary schools. No individual teachers' names were recorded, to ensure anonymity.

\subsection{Statistical Treatment of Data}

For each of the eight traits listed in section 1, a teacher's ranking of 1 (most important) was awarded three points, while a ranking of two was given 2 points, and a ranking of 3 was given 1 point. Non-ranked traits were given zero points. For each of the eight items, the points were totalled, so that a mean ranking could be calculated. The means of the eight items were then compared in order to determine which, if any, of the traits were judged significantly more important than others. The same procedure was then repeated for the behaviors of good leaders, the traits of bad leaders, and the behaviors of bad leaders.

To determine whether there were any differences between sexes or age groups, T-tests were carried out on the frequencies of number 1, number 2, and number 3 rankings for each of the items as grouped by either sex or age group ( $<37$ or $>36$ ). The choice of age 37 was made because the median age of the sample was 37 . 
Finally, the most important traits and behaviors were compared with the results from the cultures of the Zepp seven-culture study cited above.

\subsection{Organization of Data}

The means scores of the 32 items are displayed in a table. From those means, the first, second, and third overall choice are shown for each of the four categories (traits of good leaders, etc.). These results answer the main question of the research, namely, the perception of Philippine teachers on traits and perceptions of good and bad leaders.

The Philippine tables are incorporated into a larger table with seven other countries. This illustrates the answer to sub question 1 above: the comparison of the Philippines with other cultures. The top choices are tabulated into a list of which countries value which traits and behaviors of good and bad leaders.

The results of T-tests are shown for each item, between genders, and then between old and young age groups. These comparisons are made to answer sub questions 2 and 3 above, regarding possible differences in perception due to gender or age.

\section{Results}

The questionnaire (see Appendix A) has provided the data shown below. Note that there are eight items for ranking traits of good leaders, eight for behaviors of good leaders, eight for traits of bad leaders (the opposites of the good traits), and eight for behaviors of bad leaders.

The tabulated results are shown below as frequencies of first, second, and third choice responses. For example, the 12,6 , and 4 shown below 'Intel' indicates that 12 teachers marked 'intelligent' as their first choice, 6 teachers as their second choice, and 4 teachers as their third choice. The remaining teachers left this item blank (i.e. did not rank them as important).

To calculate the mean ranking score, each first choice was given 3 points, each second choice 2 points, and each third choice 1 point. Unrated items were given 0 points. The mean of the points awarded is shown in the bottom line of each table below. For example, the mean of 1.04 for 'vision' indicates that on average, respondents rated vision as their third choice (slightly higher than 1.00).

\section{Good Traits}

$\begin{array}{ccccccccc}\text { Choice } & \text { Intel } & \text { speaker } & \text { depend } & \text { vision } & \text { friendly } & \text { honest } & \text { confid } & \text { persist } \\ 1^{\text {st }} & 12 & 5 & 12 & 14 & 5 & 27 & 4 & 13 \\ 2^{\text {nd }} & 6 & 1 & 5 & 17 & 14 & 23 & 0 & 23 \\ 3^{\text {rd }} & 4 & 4 & 12 & 18 & 9 & 21 & 7 & 14 \\ \text { Mean } & 0.58 & 0.23 & 0.64 & 1.04 & 0.58 & 1.64 & 0.21 & 1.10\end{array}$

\section{Good Behaviors}

$\begin{array}{ccccccccc}\text { Choice } & \text { well-being } & \text { moral } & \text { team } & \text { clear } & \text { respect } & \text { shared } & \text { social } & \text { challenge } \\ 1^{\text {st }} & 16 & 5 & 14 & 10 & 25 & 6 & 1 & 13 \\ 2^{\text {nd }} & 4 & 2 & 12 & 11 & 29 & 20 & 2 & 9 \\ 3^{\text {rd }} & 10 & 5 & 24 & 7 & 9 & 23 & 1 & 11 \\ \text { Mean } & 0.73 & 0.27 & 1.00 & 0.66 & 1.58 & 0.90 & 0.11 & 0.76\end{array}$

\section{Bad Traits}

$\begin{array}{ccccccccc}\text { Choice } & \text { stupid } & \text { express } & \text { inconsist } & \text { narrow } & \text { unfriend } & \text { dishon } & \text { not conf } & \text { no will } \\ 1^{\text {st }} & 12 & 1 & 17 & 23 & 7 & 24 & 2 & 3 \\ 2^{\text {nd }} & 6 & 5 & 13 & 19 & 7 & 23 & 8 & 8 \\ 3^{\text {rd }} & 8 & 1 & 14 & 10 & 25 & 7 & 11 & 13 \\ \text { Mean } & 0.62 & 0.16 & 1.01 & 1.30 & 0.67 & 1.39 & 0.37 & 0.42\end{array}$




\section{Bad Behaviors}

$\begin{array}{ccccccccc}\text { Choice } & \text { ego } & \text { selfish } & \text { no team } & \text { not clear } & \text { children } & \text { dictator } & \text { criticism } & \text { corrupt } \\ 1^{\text {st }} & 20 & 6 & 12 & 6 & 1 & 25 & 4 & 14 \\ 2^{\text {nd }} & 8 & 5 & 11 & 14 & 7 & 23 & 6 & 14 \\ 3^{\text {rd }} & 13 & 3 & 16 & 8 & 4 & 18 & 8 & 18 \\ \text { Mean } & 0.9 & 0.34 & 0.82 & 0.60 & 0.23 & 1.54 & 0.36 & 0.98\end{array}$

\subsection{Summary of Results for Main Question}

The following table summarizes which items had the highest overall mean rankings.

\section{Traits of Good Leaders}

$\begin{array}{lll}\text { Highest: } & \text { Honesty } & \text { (mean 1.64) } \\ \text { Second } & \text { Persistence } & \text { (mean 1.10) } \\ \text { Third } & \text { Vision } & \text { (mean 1.04) }\end{array}$

Behaviors of Good Leaders

$\begin{array}{lll}\text { Highest } & \text { Shows Respect } & \text { (mean 1.58) } \\ \text { Second } & \text { Teamwork } & \text { (mean 1.00) } \\ \text { Third } & \text { Shared decisions } & \text { (mean 0.90) }\end{array}$

\section{Traits of Bad Leaders}

$\begin{array}{lll}\text { Highest } & \text { Dishonest } & \text { (mean 1.39) } \\ \text { Second } & \text { Narrow-minded } & \text { (mean 1.30) } \\ \text { Third } & \text { Inconsistent } & \text { (mean 1.01) }\end{array}$

Behaviors of Bad Leaders

Highest Behaves like Dictator (mean 1.54)

Second Promotes own ego (mean 0.99)

Third Corruption (mean 0.98)

4.2 Sub Question One: Do Philippine Teachers Have Similar Perceptions of Leadership to Teachers in Other Countries?

A thorough discussion of this question is treated in the final chapter of this paper. For the purposes of this chapter, it suffices to state that Philippine teachers rated honesty as the most important trait of good leaders, and dishonesty as the most important trait of bad leaders. This result is slightly different from other countries, where intelligence or dependability were judged most important.

By way of comparison, the results of American teachers who took the same questionnaire were as follows (Zepp, 2009):

Traits of Good Leaders

$\begin{array}{lll}\text { Highest: } & \text { Consistent } & \text { (mean 1.67) } \\ \text { Second } & \text { Honest } & \text { (mean 1.30) } \\ \text { Third } & \text { Persistent } & \text { (mean 1.11) }\end{array}$


Behaviors of Good Leaders

$\begin{array}{lll}\text { Highest } & \text { Respect } & \text { (mean 1.37) } \\ \text { Second } & \text { Shared Decisions } & \text { (mean 1.30) } \\ \text { Third } & \text { Challenges us } & \text { (mean 0.90) }\end{array}$

Traits of Bad Leaders

$\begin{array}{lll}\text { Highest } & \text { Inconsistent } & \text { (mean 1.77) } \\ \text { Second } & \text { Dishonest } & \text { (mean 1.08) } \\ \text { Third } & \text { Narrow-minded } & \text { (mean 1.01) }\end{array}$

Behaviors of Bad Leaders

$\begin{array}{lll}\text { Highest } & \text { Dictator } & \text { (mean 1.17) } \\ \text { Second } & \text { Ego } & \text { (mean 0.96) } \\ \text { Third } & \text { Unclear } & \text { (mean 0.93) }\end{array}$

\subsection{Sub Question Two: Do Male and Female Philippine Teachers Share Similar Perceptions of Leadership?}

The sample was composed of only 18 men and 72 women. This is a typical ratio for Philippine schools. Mean rankings were calculated for the men and for the women to see whether men and women responded differently to any of the items.

Means by Sex

\section{Good Traits}

$\begin{array}{lcccccccc}\text { Means } & \text { Intel } & \text { speaker } & \text { depend } & \text { vision } & \text { friendly } & \text { honest } & \text { confid } & \text { persist } \\ \text { Women } & 0.53 & 0.24 & 0.74 & 0.94 & 0.59 & 1.63 & 0.24 & 1.15 \\ \text { Men } & 0.61 & 0.11 & 0.33 & 1.50 & 0.61 & 1.83 & 0.17 & 0.83\end{array}$

\section{Good Behaviors}

$\begin{array}{lccccccccc}\text { Mean } & \text { well-being } & \text { moral } & \text { team } & \text { clear } & \text { respect } & \text { shared } & \text { social } & \text { challenge } \\ \text { Women } & 0.84 & 0.25 & 1.01 & 0.71 & 1.50 & 0.88 & 0.10 & 0.71 \\ \text { Men } & 0.28 & 0.17 & 0.83 & 0.61 & 2.22 & 0.89 & 0.17 & 0.83\end{array}$

\section{Bad Traits}

$\begin{array}{lcccccccc}\text { Mean } & \text { stupid } & \text { express } & \text { inconsist } & \text { narrow } & \text { unfriend } & \text { dishon } & \text { not conf } & \text { no will } \\ \text { Women } & 0.71 & 0.13 & 0.97 & 1.40 & 0.78 & 1.25 & 0.34 & 0.43 \\ \text { Men } & 0.44 & 0.28 & 1.17 & 1.06 & 0.28 & 1.94 & 0.17 & 0.33\end{array}$

\section{Bad Behaviors}

$\begin{array}{lcccccccc}\text { Mean } & \text { ego } & \text { selfish } & \text { no team } & \text { not clear } & \text { children } & \text { dictator } & \text { criticism } & \text { corrupt } \\ \text { Women } & 1.03 & 0.38 & 0.87 & 0.68 & 0.15 & 1.44 & 0.37 & 1.00 \\ \text { Men } & 0.67 & 0.28 & 0.72 & 0.28 & 0.39 & 1.83 & 0.39 & 1.11\end{array}$

Significant differences between men and women were found for three of the variables, with nearly significant differences for two other variables. They were as follows: 
"He/she treats us with respect"

$$
\text { Men mean } 2.35 \text { Women mean } 1.47 \quad \mathrm{t}=2.895 \quad \text { sign. } \mathrm{p}<.005
$$

"He/she has an unfriendly personality"

$$
\text { Men mean } 0.28 \text { Women mean } 0.78 \quad \mathrm{t}=2.054 \quad \text { sign } \quad \mathrm{p}<.037
$$

"He/she is dishonest and deceitful."

$$
\text { Men mean } 1.94 \text { Women mean } 1.25 \quad \mathrm{t}=2.125 \quad \text { sign } \quad \mathrm{p}<.043
$$

"He/she has a broad vision which he/she shares with us"

$$
\text { Men mean } 1.50 \text { Women mean } 0.94 \quad t=1.911 \quad \text { sign } \quad p<.059
$$

"He/she attend to our well-being and human needs."

$$
\text { Men mean } 0.28 \quad \text { Women mean } 0.84 \quad \mathrm{t}=1.841 \quad \text { sign } \quad \mathrm{p}<.069
$$

Thus, men were almost unanimous in choosing honesty as their most important trait, while women rated it highly, but not as highly as did the men. Similarly, men ranked dishonesty as more important for bad leadership than did the women.

Men were more likely to value broad vision, while women attached more importance to personal traits and behaviors such as attending to our well-being, or having an unfriendly personality.

4.4 Sub Question Three: Do Older and Younger Philippine Teachers Share Similar Perceptions on Leadership?

Mean rankings were computed for each age group. The median age of the sample was 37, so all respondents under 37 were considered 'young', while those 37 and older were considered 'old'. Mean rankings were calculated for the young group and the old group.

Means by Age Group

Good Traits

$\begin{array}{lcccccccc}\text { Mean } & \text { Intel } & \text { speaker } & \text { depend } & \text { vision } & \text { friendly } & \text { honest } & \text { confid } & \text { persist } \\ \text { Young } & 0.76 & 0.19 & 0.64 & 1.10 & 0.71 & 1.57 & 0.21 & 0.88 \\ \text { Old } & 0.41 & 0.27 & 0.70 & 0.89 & 0.50 & 1.75 & 0.23 & 1.25\end{array}$

\section{Good Behaviors}

$\begin{array}{lcccccccc}\text { Mean } & \text { well-being } & \text { moral } & \text { team } & \text { clear } & \text { respect } & \text { shares } & \text { social } & \text { challenge } \\ \text { Young } & 0.64 & 0.31 & 1.21 & 0.90 & 1.57 & 0.86 & 0.07 & 0.43 \\ \text { Old } & 0.41 & 0.27 & 0.70 & 0.89 & 0.50 & 1.75 & 0.23 & 1.25\end{array}$

\section{Bad Traits}

$\begin{array}{llllccccc}\text { Mean } & \text { stupid } & \text { express } & \text { inconsist } & \text { narrow } & \text { unfriend } & \text { dishon } & \text { not conf } & \text { no will } \\ \text { Young } & 0.36 & 0.17 & 1.19 & 1.31 & 0.71 & 1.40 & 0.29 & 0.43 \\ \text { Old } & 0.89 & 0.16 & 0.86 & 1.30 & 0.66 & 1.32 & 0.43 & 0.39\end{array}$

\section{Bad Behaviors}

$\begin{array}{lcccccccc}\text { Mean } & \text { ego } & \text { selfish } & \text { no team } & \text { not clear } & \text { children } & \text { dictator } & \text { criticism } & \text { corrupt } \\ \text { Young } & 0.57 & 0.19 & 0.95 & 0.62 & 0.19 & 1.83 & 0.48 & 0.88 \\ \text { Old } & 1.36 & 0.48 & 0.68 & 0.57 & 0.30 & 1.25 & 0.27 & 1.09\end{array}$


The older half of the sample (>36 years) showed significant differences from the younger half $(<37)$ on three variables, and near significance on a fourth, as follows:

"He/she challenges us to perform at our highest possible level."

$$
\text { Old mean } 1.00 \quad \text { Young mean } 0.43 \quad \mathrm{t}=2.449 \quad \text { sign } \quad \mathrm{p}<.016
$$

"He/she is stupid."

$$
\text { Old mean } 0.89 \text { Young mean } 0.36 \quad \mathrm{t}=2.270 \quad \text { sign } \quad \mathrm{p}<.026
$$

"He/she engages in corruption or nepotism."

Old mean 1.36 Young mean $0.57 \quad \mathrm{t}=3.092$ sign $\mathrm{p}<.003$

"He/she gives very clear instructions."

Old mean $0.45 \quad$ Young mean $0.90 \quad \mathrm{t}=1.947 \quad$ sign $\quad \mathrm{p}<.055$

Thus, the older half of the sample placed greater importance on challenging to perform, stupidity, and corruption in evaluating good or bad leaders, while the younger half valued clear instructions more than did the older half.

\subsection{Summary of Results}

In answer to the main research question, Philippine teachers chose the following:

$$
\begin{array}{ll}
\text { Most Important trait of good leaders } & \text { Honesty } \\
\text { Most important behavior of good leaders } & \text { Showing Respect } \\
\text { Most important trait of bad leaders } & \text { Dishonesty } \\
\text { Most important behavior of bad leaders } & \text { Acting like a Dictator }
\end{array}
$$

\section{Sub Question One - Comparison with Other Countries}

The main difference between Philippine teachers and teachers in seven other cultures was the emphasis on honesty, whereas other countries emphasized intelligence or dependability.

\section{Sub Question Two - Gender Differences}

Men differed from women in three main items:

1. Men valued showing respect much higher than did women.

2. Women disliked unfriendly behavior more than did men.

3. Men valued honesty even more than did women (although valued It highly).

\section{Sub Question Three -- Age Differences}

Older teachers differed from younger teachers on three items:

1. Older teachers valued the behavior "challenges us to perform" more highly than did younger teachers.

2. Older teachers disliked dishonesty more than did younger teachers.

3. Older teachers disliked corruption much more than did younger teachers.

\section{Discussion and Summary}

In general, research into leadership has evolved from a theory of universal traits and behaviors possessed naturally by all great leaders around the world, to a host of 'contingency' theories, whereby traits and behaviors of good leaders are contingent on situations, professions, and cultures.

Perceptions of leadership have been studied in many countries and cultures (e.g. Zepp et. al. (2009a)) Few studies have included the Philippines. The same questionnaire used by Zepp (2009a) for the seven-culture comparison used a sample of 90 teachers in northern Philippines.

With a weighting of three points for each first choice, two for each second choice, and one for each third choice (and zero for items not chosen), it was possible to calculate a mean score (over all the 90 teachers) for each of the 32 
items ( 8 good traits, 8 good behaviors, 8 bad traits, and 8 bad behaviors). These mean scores could then be compared to see which of the items were the considered the most important by the teachers.

Since this method had been used in other studies, the Philippine results could then be compared with those of other cultures to see whether Philippine teachers considered the same traits and behaviors important for good and bad leaders as did teaches in other countries.

Mean scores were also calculated between male and female teachers, as well as between older ( $>36$ years) and younger (>37 years) teachers.

\subsection{Results of the Sub Questions}

Sub question 1: How do Philippine teachers compare with those in other countries with regard to their perceptions of leadership?

It is useful to compare the Philippine results with those of the study of Zepp (2009a) of seven other cultures. Those results are shown below, with the Philippine results listed first.

\section{Traits of Good Leaders}

$\begin{array}{llll} & \text { Highest } & \text { Second } & \text { Third } \\ \text { Philippines } & \text { Honest (1.64) } & \text { Persistent (1.10) } & \text { Vision (1.04) } \\ \text { Taiwan } & \text { Dependable (1.60) } & \text { Honest (1.14) } & \text { Intelligent (0.77) } \\ \text { Qatar } & \text { Vision (1.22) } & \text { Persistent (1.03) } & \text { Dependable (0.91) } \\ \text { Hong Kong } & \text { Dependable (1.38) } & \text { Vision (1.27) } & \text { Intelligent (1.17) } \\ \text { Uganda } & \text { Intelligent (1.04) } & \text { Vision (0.93) } & \text { Speaking (0.89) } \\ \text { Cambodia } & \text { Persistent (1.81) } & \text { Intelligent (1.76) } & \text { Honest (1.63) } \\ \text { Pakistan } & \text { Intelligent (1.38) } & \text { Honest (0.79) } & \text { Friendly (0.77) } \\ \text { USA } & \text { Dependable (1.67) } & \text { Honest (1.30) } & \text { Persistent (1.11) }\end{array}$

Note that the Philippine teachers were the only group to rate honesty as the most important trait, even though four of the other seven countries included honesty as second or third choices. For three of the countries - Qatar, Hong Kong, and Uganda -- honesty did not even appear among the top three traits of good leaders.

A second comment is that Intelligence was not listed among the top three by Philippine teachers. It was only tied for $5^{\text {th }}-6^{\text {th }}$ place with Friendliness at 0.58 . Intelligence appeared in the top three of 5 of the other 7 countries, and was number one in both Uganda and Pakistan.

Similarly, Dependability was rated tops by Taiwan, Hong Kong, and the USA, but was only fourth at 0.64 among Philippine teachers.

\section{Behaviors of Good Leaders}

$\begin{array}{llll}\text { Philippines } & \text { Shows Respect (1.58) } & \text { Teamwork (1.00) } & \text { Shared Decisions (0.90) } \\ \text { Taiwan } & \text { Teamwork (1.46) } & \text { Respect (1.38) } & \text { Our Well-being (0.79) } \\ \text { Qatar } & \text { Teamwork (1.12) } & \text { Shared Dec. (1.08) } & \text { Respect (1.05) } \\ \text { Hong Kong } & \text { Respect (1.61) } & \text { Teamwork (1.38) } & \text { Performance (0.88) } \\ \text { Uganda } & \text { Teamwork (1.22) } & \text { Respect (1.16) } & \text { Shared Dec. (1.16) } \\ \text { Cambodia } & \text { Morals (1.68) } & \text { Well-being (1.21) } & \text { Shared Dec. (1.08) } \\ \text { Pakistan } & \text { Respect (1.14) } & \text { Teamwork (1.12) } & \text { Our well-being (0.83) } \\ \text { USA } & \text { Respect }(1.37) & \text { Performance (1.30) } & \text { Shared Dec. }(0.90)\end{array}$


Showing respect led the Philippine list with a high mean of 1.58. Teamwork and Shared decision-making were a distant second and third with means of only 1.00 and 0.90 , respectively. This result was consistent with the other countries, where Respect was listed by six of the seven countries, coming in first place in Hong Kong, Pakistan, and the United States. Teamwork was mentioned by five of the seven, and was ranked first in three other countries. Shared decision-making was listed by four of the seven other countries. It would seem that these three behaviors showing respect, teamwork, and shared decision-making, are nearly universal in their desirability in good leaders.

\section{Traits of Bad Leaders}

$\begin{array}{llll}\text { Philippines } & \text { Dishonest (1.39) } & \text { Narrow-minded (1.30) } & \text { Inconsistent (1.01) } \\ \text { Taiwan } & \text { Dishonest (1.68) } & \text { Inconsistent (1.47) } & \text { Unfriendly (0.97) } \\ \text { Qatar } & \text { Inconsistent (1.08) } & \text { Narrow-minded (0.95) } & \text { No willpower (0.94) } \\ \text { Hong Kong } & \text { Dishonest (1.65) } & \text { Inconsistent (1.28) } & \text { Narrow minded (1.18) } \\ \text { Uganda } & \text { Dishonest (1.03) } & \text { Unfriendly (0.98) } & \text { Inconsistent (0.94) } \\ \text { Cambodia } & \text { No Willpower (1.15) } & \text { Stupid (1.08) } & \text { Dishonest (0.96) } \\ \text { Pakistan } & \text { Stupid (1.31) } & \text { Dishonest (0.94) } & \text { Narrow minded (1.01) } \\ \text { USA } & \text { Inconsistent (1.77) } & \text { Dishonest (1.08) } & \text { Narrow minded (1.01) }\end{array}$

Here, dishonesty was the clear winner, as it was ranked first by three countries in addition to the Philippines, and was in the top three of all but one of the countries (Qatar). Note that Qatar was at least consistent in not listing honesty as a trait of good leaders, and that the Philippines consistently placed honesty and dishonesty at the head of the list of good and bad leaders, respectively.

\section{Behaviors of Bad Leaders}

$\begin{array}{llll}\text { Philippines } & \text { Dictator (1.54) } & \text { Own ego (0.99) } & \text { Corruption (0.98) } \\ \text { Taiwan } & \text { As children (1.21) } & \text { Own ego (1.13) } & \text { Not Clear (1.04) } \\ \text { Qatar } & \text { Own ego (1.23) } & \text { Dictator }(1.14) & \text { No teamwork (0.86) } \\ \text { Hong Kong } & \text { As children (1.16) } & \text { Not Clear (1.01) } & \text { Corruption }(0.96) \\ \text { Uganda } & \text { Dictator }(1.18) & \text { Own ego }(0.94) & \text { No criticism }(0.90) \\ \text { Cambodia } & \text { Corruption (1.39) } & \text { Own ego }(1.37) & \text { Selfish }(1.06) \\ \text { Pakistan } & \text { Own ego }(1.21) & \text { Dictator }(1.03) & \text { No teamwork (0.97) } \\ \text { USA } & \text { Dictator }(1.17) & \text { Own ego }(0.96) & \text { Not clear }(0.93)\end{array}$

Philippine teachers gave 'Acting like a Dictator' a mean ranking of 1.54, far ahead of any other behavior of bad leaders. Even promoting one's own ego, and engaging in corruption had mean rankings below 1.00.

Four other countries listed Dictator among their choices, with two - Uganda and USA - ranking it first alongside the Philippines. Taiwan Hong Kong, and Cambodia did not list Dictator among their top three choices.

Only Hong Kong did not rank Promoting one's own ego among their top three choices. Corruption, on the other hand, was listed by only two countries other than the Philippines - Hong Kong and Cambodia.

Sub question Two: Do male and female Philippine teachers share similar perceptions of leadership?

Significant differences between men and women were found for three of the variables, with nearly significant differences for two other variables. They were as follows: 
"He/she treats us with respect"

$$
\text { Men mean 2.35 Women mean } 1.47 \quad \mathrm{t}=2.895 \quad \text { sign. } \mathrm{p}<.005
$$

"He/she has an unfriendly personality"

$$
\begin{array}{lllllll}
\text { Men mean } & 0.28 & \text { Women mean } 0.78 & \mathrm{t}=2.054 & \text { sign. } & \mathrm{p}<.037
\end{array}
$$

"He/she is dishonest and deceitful."

Men mean 1.94 Women mean $1.25 \quad \mathrm{t}=2.125 \quad$ sign $\mathrm{p}<.043$

"He/she has a broad vision which he/she shares with us"

Men mean 1.50 Women mean $0.94 \quad t=1.911 \quad$ sign $\quad p<.059$

"He/she attend to our well-being and human needs."

$$
\begin{array}{lllllll}
\text { Men mean } & 0.28 & \text { Women mean } & 0.84 & \mathrm{t}=1.841 & \text { sign } & \mathrm{p}<.069
\end{array}
$$

Thus, men were almost unanimous in choosing honesty as their most important trait, while women rated it highly, but not as highly as did the men. Similarly, men ranked dishonesty as more important for bad leadership than did the women.

Men were more likely to value broad vision, while women attached more importance to personal traits and behaviors such as attending to our well-being, or having an unfriendly personality.

Sub question three: Do older and younger Philippine teachers share similar perceptions on leadership?

The older half of the sample (>36 years) showed significant differences from the younger half $(<37)$ on three variables, and near significance on a fourth, as follows:

"He/she challenges us to perform at our highest possible level."

$$
\text { Old mean } 1.00 \quad \text { Young mean } 0.43 \quad \mathrm{t}=2.449 \quad \text { sign } \quad \mathrm{p}<.016
$$

"He/she is stupid."

Old mean 0.89 Young mean $0.36 \quad \mathrm{t}=2.270$ sign $\mathrm{p}<.026$

"He/she engages in corruption or nepotism."

Old mean $1.36 \quad$ Young mean $0.57 \quad \mathrm{t}=3.092 \quad$ sign $\quad \mathrm{p}<.003$

"He/she gives very clear instructions."

Old mean $0.45 \quad$ Young mean $0.90 \quad \mathrm{t}=1.947 \quad$ sign $\quad \mathrm{p}<.055$

Thus, the older half of the sample placed importance on challenging to perform, stupidity, and corruption in evaluating good or bad leaders, while the younger half valued clear instructions.

The most significant difference was in the importance of corruption and nepotism. The older teachers gave a very high 1.36 to the importance of corruption, while the younger half rated it only 0.57 , quite a low mean rating for such an important issue in Philippine society. One may speculate that the older teachers had experienced the corruption of the Ferdinand Marcos regime in the Philippines years ago.

\subsection{Summary of Main Question Results}

As a result of the questionnaire answered by 90 teachers, the answers to the main question were clear. Philippine teachers valued Honesty far above other traits of good leaders, with a mean ranking of 1.64. In second place was Persistence, with a mean of 1.10, followed closely in third place by Vision, with a mean of 1.04.

As for behaviors of good leaders, Showing respect was valued most highly at 1.58 , followed by Teamwork (1.00) and Shared Decision-making (0.90).

As for traits of bad leaders, as might be expected from the high ranking of honesty for good leaders, dishonesty was rated most important at 1.39, followed by Narrow-mindedness and Inconsistency, at mean rankings of 1.30 and 1.01, respectively. 
As for behaviors of bad leaders, Behaving like a Dictator was most important at 1.54 , followed distantly by Promoting one's own Ego (0.99), and Engaging in Corruption (0.98).

\subsection{Relationship of Research to the Field}

The results add one more building block into the understanding of leadership across cultures, and support general findings that leadership is perceived differently in various cultures, notably in the perceptions of the traits and behaviors of good and bad leaders. General findings in the Philippines have been largely limited to studies of government sector leadership, while the educational sector has gone relatively unstudied. (Luna, 2012)

Most leadership programs in the Philippines launched by the government and/or sponsored by other countries focus more on training for government positions and fail to represent other sectors especially education.

The current study is therefore an attempt to examine the perceptions of leadership in the Philippine educational sector. Even within that focus, the study looks only at teachers, not students or administrators, who might have different perceptions of leadership.

This paper in fact found a rather unique focus of Philippine teachers. The Philippine emphasis on honesty as the key component of leadership is an interesting divergence from other countries, where intelligence or dependability occupy the highest rank. Also, the differences between men teachers and women teachers, as well as between old teachers and young teachers, provide fertile grounds for further research in other cultures.

\subsection{Discussion of Results}

The study revealed differences between cultural perceptions of good and bad leaders. Thus, there is no one universal ideal of leadership traits or behaviors around the world. For example, Philippine teachers valued honesty above all other traits and ranked intelligence only a lowly $5^{\text {th }}$, while other teachers in other countries valued intelligence as the most important trait of a leader.

Even among Philippine teachers, there were significant differences between subgroups, namely between men and women, and between old and young teachers. There may be many other subcultures where differences may occur. Indeed, Zepp (2009b) found that Cambodian students have different perceptions from Cambodian teachers. He also found differences among three professions in Cambodia (Zepp, 2011). Thus, even to claim that Philippine teachers responded a certain way to the questionnaire is not to claim that Filipinos of all walks of life will respond in the same way.

One limitation of the study was the prevalence of female teachers over male teachers. The sample of 90 teachers had only 18 males, and this ratio appears to be common in Philippine schools, especially elementary schools.

The results may be useful in hiring and firing school principals and other educational leaders. According to the results of this study, In the Philippines an honest candidate should be chosen ahead of an intelligent one, all other qualities being equal. Hiring and firing may also be affected if the school has a younger or older teaching staff, or whether there are many more female than male teachers.

\subsection{Conclusion}

The study revealed differences between cultural perceptions of good and bad leaders. Philippine teachers valued honesty above all other traits and ranked intelligence only a lowly $5^{\text {th }}$, while other teachers in other countries valued intelligence as the most important trait of a leader. Even among Philippine teachers, there were significant differences between subgroups, namely between men and women, and between old and young teachers. These findings support other international research in the finding that not only do different cultures have different perceptions of leadership, but also that various subcultures such as men-women, old-young, and different professions, may view leadership in different lights.

\section{References}

Baldauf, R.B., \& Robert, B.K. (2006). Language Planning and Policy in the Pacific. Clevedon, U.K.: MPG Books.

Blake, R., \& Mouton, J. (1964). The Managerial Grid: The Key to Leadership Excellence. Houston: Gulf Publishing Co.

Bumatay, E. (2004). Leadership in Higher Education Institutions: Perspectives of Filipino Academic Deans. Doctoral Dissertation, University of the Philippines Diliman, Quezon City. 
Carlisle, T. (1840). On Heroes, Hero-Worship, and the Heroic in History. Retrieved 19 June 2015, from http://history.furman.edu/benson/fywbio/carlyle_great_man.htm

Fiedler, F.E. (1967). A Theory of Leadership Effectiveness. New York: McGraw-Hill.

Hershock, P., et al.. (2007). Changing Education: Leadership Innovation and Development in a Globalizing Asia Pacific. Hong Kong: Springer.

Hofstede, G. (1983). International Studies of Management \& Organization. JSTOR, XIII(1-2), 46-74.

Hofstede, G. (1984). Culture's Consequences: International Differences in Work-Related Values (2nd ed.). Beverly Hills CA: SAGE Publications.

House, R.J., Hanges, P.J., Javidan, M., Dorfman, P.W., \& Gupta, V. (eds.). (2004). Culture, Leadership, and Organizations: The GLOBE Study of 62 Societies. Thousand Oaks: Sage Publications.

Jones, M.L. (2007). Hofstede - Culturally Questionable?. Oxford Business and Economics Conference, Oxford, UK, June 2007.

Likert, R. (1961). New patterns of management. NY: McGraw-Hill

Luna, K. (2012). Educational Leadership in the Philippines. The Moon and Star. Retrieved 12 May 2015, from http://lunakatrina.blogspot.com/2012/10/educational-leadership-in-philippines.html

Napire, J.N. (2013). Adversity Quotient and Leadership Style in Relation to the Demographic Profile of the Elementary School Principals in the Second Congressional District of Camarines Sur. Doctoral Dissertation, University of Northeastern Philippines, Iriga City.

San Antonio, Diosdado M., \& David, T. G. (2006). Democratic school leadership: Its impact on the commitment of educational stakeholders School of Education. The University of Newcastle, Australia: Australian Association for Research in Education. Retrieved 18 June 2015, from www.aare.edu.au/data/publications/2006/san06332.pdf

Sindhvad, S.P. (2009). School Principals as Instructional Leaders: An Investigation of School Leadership Capacity in the Philippines Doctoral Dissertation, University of Minnesota.

Stogdill, R.M. (1948). Personal factors associated with leadership: A survey of the literature. Journal of Psychology, 25, 35-71. https://doi.org/10.1080/00223980.1948.9917362

Zepp, R., et al.. (2009a, February 19). Teachers' Perceptions of Good and Bad Leaders in Seven Cultures. Academic Leadership Journal, 7.

Zepp, R. (2009b, April). Perceptions of Leadership by Cambodian Teachers and Students. Pannasastra University Research Series, 1.

Zepp, R. (2011, January). Perceptions of Leadership in Three Professions in Cambodia. International Journal of Business and Social Science, 2(3), 233-237.

Zialcita, F. (2005). Authentic, though not Exotic. Manila: Ateneo de Manila University Press.

\section{Appendix A: Leadership Questionnaire}

\section{Sex (circle one) $\quad M \quad F \quad$ Age}

Instructions. Place a ' 1 ' in the blank next to the most important of the eight traits of good leaders listed below. Then place a ' 2 ' for the second most important, and then a ' 3 ' for the third most important. Do not rank th $4^{\text {th }}, 5^{\text {th }}, 6^{\text {th }}$, etc.

Traits of Good Leaders

$\mathrm{He} / \mathrm{she}$ is very intelligent.

$\mathrm{He} / \mathrm{she}$ is a good public speaker.

$\mathrm{He} / \mathrm{she}$ is dependable and consistent.

$\mathrm{He} / \mathrm{she}$ has a broad vision which he/she shares with us. 
$\mathrm{He} / \mathrm{she}$ has a very friendly personality.

$\mathrm{He} / \mathrm{she}$ is honest and we can trust him/her.

$\mathrm{He} / \mathrm{she}$ is very self-confident.

$\mathrm{He} /$ she shows persistence and determination in achieving goals.

\section{Behaviors of Good Leaders}

$\mathrm{He} / \mathrm{she}$ attends to our well-being and human needs.

$\mathrm{He} / \mathrm{she}$ appeals to our higher moral selves.

$\mathrm{He} / \mathrm{she}$ works with us as a team.

$\mathrm{He} / \mathrm{she}$ gives very clear instructions.

$\mathrm{He} / \mathrm{she}$ treats us with respect.

$\mathrm{He} / \mathrm{she}$ invites us to share in the decision-making.

$\mathrm{He} / \mathrm{she}$ seeks to improve social relationships.

$\mathrm{He} /$ she challenges us to perform at our highest possible level.

Instructions p.2. Place a ' 1 ' in the blank next to the most important of the eight traits of bad leaders listed below. Then place a ' 2 ' for the second most important, and then a ' 3 ' for the third most important. Do not rank th $4^{\text {th }}, 5^{\text {th }}, 6^{\text {th }}$, etc.

Traits of Bad Leaders

$\mathrm{He} / \mathrm{she}$ is stupid.

$\mathrm{He} / \mathrm{she}$ cannot express himself/herself well.

$\mathrm{He} / \mathrm{she}$ is not consistent between what he/she says and what he/she does.

$\mathrm{He} / \mathrm{she}$ is narrow-minded.

$\mathrm{He} / \mathrm{she}$ has an unfriendly personality.

$\mathrm{He} / \mathrm{she}$ is dishonest and deceitful.

$\mathrm{He} / \mathrm{she}$ is not confident about achieving our tasks.

$\mathrm{He} / \mathrm{she}$ does not have a strong will to succeed.

\section{Behaviors of Bad Leaders}

$\mathrm{He} / \mathrm{she}$ works only to improve his/her own ego and self-promotion.

$\mathrm{He} / \mathrm{she}$ appeals to our selfishness.

$\mathrm{He} / \mathrm{she}$ shows no sense of teamwork.

$\mathrm{He} / \mathrm{she}$ doesn't make it clear what he/she wants us to do.

$\mathrm{He} / \mathrm{she}$ treats us like naughty children.

$\mathrm{He} / \mathrm{she}$ acts like a dictator.

He/she fears and discourages criticism and opposition.

$\mathrm{He} / \mathrm{she}$ engages in corruption or nepotism. 